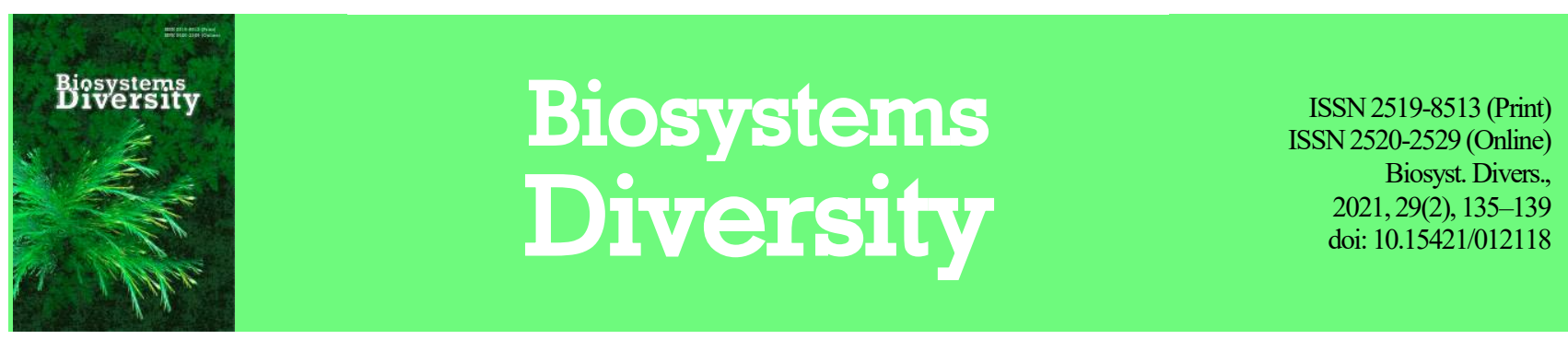

\title{
Parasites of domestic and wild pigeons in the south of Ukraine
}

\author{
M. Bogach*, A. Paliy*, P. Liulin**, L. Perots'ka***, O. Bohach****, I. Pyvovarova***, A. Palii***** \\ *Institute of Experimental and Clinical Veterinary Medicine, Kharkiv, Ukraine \\ **Kharkiv State Zooveterinary Academy, Malaya Danilovka, Ukraine \\ ***Odesa State Agrarian University, Odesa, Ukraine \\ ****State Research Control Institute of Veterinary Drugs and Feed Additives, Lviv, Ukraine \\ *****Kharkiv Petro Vasylenko National Technical University of Agriculture, Kharkiv, Ukraine
}

Article info

Received 20.04.2021

Received in revised form 25.05 .2021

Accepted 27.05.2021

Institute of Experimental and Clinical Veterinary Medicine Pushkinska st., 83, Kharkiv, 61023. Ukraine.

Tel.: +38-067-997-49-25. E-mail: bogach_n@@ukr.net

Kharkiv State Zooveterinary Academy, Akademichna st., 1 , Malaya Danilovka, Derhachivskyi district, Kharkiv region, 62341, Ukraine. Tel.: +38-097-148-40-02.

E-mail:liulinpetr@gmail.com

State Research Control Institute of Veterinary Dnugs and Feed Additives, Donetska st., 11, Lviv, 79019, Ukraine. Tel. +38-096-641-21-55.E-mail:olena.bohach.m@gmail.com

Odesa State Agrarian University, Panteleymonovska st., 13 Odesa 65000 Ulkraine. Tel: $+38-067-785-61-94$.

E-mail:perotskaya@ukr.net

Kharkiv Petro Vasylenko National Technical University of Agriculture, Alcherskyh st., 44, Kharkiv, 61002, Ukraine. Tel.: +38-063-712-82-42.E-mail:paliy.andriy@ukr.net
Bogach, M., Paliy, A., Liulin, P., Perots'ka, L., Bohach, O., Pyvovarova, I., \& Palii, A. (2021). Parasites of
domestic and wild pigeons in the south of Ukraine. Biosystems Diversity, 29(2), 135-139. doi:10.15421/012118

Pigeons are closely related to human life and are both a source of food and object for hobbies and sports. Parasitic diseases of birds are the main reason for their growth retardation, reduced productivity and viability. The article presents the results of studying the prevalence of trichomonosis, cestodes and nematodes among the population of wild and domestic pigeons in the south of Ukraine. According to the results of the conducted researches it is established that in the south of Ukraine endoparasitoses of domestic and wild pigeons are quite widespread, and all species of this bird are carriers of Trichomonas gallinae. At the same time, the highest rate of Trichomonas infection was recorded in Columba palambus and C. livia domestica, and the overall infestation of males is higher by $4.4 \%$ compared to females. It was determined that domestic pigeons $C$. livia domestica were infested with trichomonosis (27.5\%) and nematodes (Ascaridia columbae, 57.1\%), C. palambus - trichomonosis (32.1\%) and cestodes (Raillietina spp., 82.4\%), Streptopelia turtur - cestodes (Raillietina spp., 12.5\%) and S. decaocto - cestodes (Raillietina spp., 71.4\%) and nematodes (Heterakis gallinarum, A. columbae - 33.3\% and 44.4\% respectively). The overall rate of infestation of pigeons with cestodes was $28.4 \%$ and the incidence in males was higher by $3.9 \%$ compared to females. It was found that the most common species among pigeon cestodes is Raillietina spp. In addition, $22.9 \%$ of pigeons are carriers of nematodes (H. gallinarum, A. columbae and Capillaria spp.). Continuous monitoring of pigeon parasites is necessary because they, in most cases, come into contact with other species of poultry and are a source of general invasion. In terms of further research, it would be promising to study the prevalence of helminthic infestation among wild migratory birds.

Keywords: trichomonosis; cestodes; nematodes; epizootic process; distribution.

\section{Introduction}

Ecological and geographical features of the territory are the most important factor in the development of the epizootic process (Boyko \& Brygadyrenko, 2018, 2019). In this respect, the south of Ukraine is a unique natural and climatic territory for the intensive development of poultry farming. In addition, millions of migrant birds from around the world stop over in this area every year during spring and autumn. This has largely historically determined the role of Southern Ukraine in the existence of a unique and typical bird helminth fauna.

Given the importance of controlling parasitic diseases for many countries around the world, the 54th World Health Assembly agreed on a strategy to control helminthiasis in animals and birds. Some researchers believe that intestinal parasitoses are primarily a sanitary problem and their prevention should be based on sanitary and parasitological monitoring (Leung \& Koprivnikar, 2016; Moravec \& Scholz, 2016; Boyko \& Brygadyrenko, 2017). One of the main tasks of ecological parasitology at the present stage is to establish patterns of spread of invasive diseases of poultry in the environment through a thorough epidemiological examination, as well as to determine the main directions and factors of spread of parasites in Ukraine (Nakao et al., 2019; Paliy et al., 2020). Helminthiasis has a particularly detrimental or debilitating effect on infected birds, mainly young individuals, slowing growth and preventing healthy development, as well as making adult birds prone to secondary infections (Hembram et al., 2015). Studies by Rohde (1994) show that temperature, humidity, rainfall, feeding habits of the host, the presence of infectious hosts and parasites, as well as the maturation of parasites are among the important factors influencing the development of parasitic infections.

Pigeons, due to their close interaction with humans and other domestic and wild birds, serve as a potential reservoir of zoonotic parasites (Adang et al., 2008). Both domestic and wild pigeons are not harmless birds, they can serve as hidden potential reservoirs of too many human diseases, and can also transmit parasitic diseases to animals and poultry (Piasecki, 2006). The authors suggest that wild pigeons and domestic pigeons are usually infected with internal and external parasites through a common power source (Ali et al., 2020).

Cities and suburbs are home to a large number of pigeons of various breeds, including wild pigeons, which are permanent residents of parks, playgrounds, markets and other facilities and can serve as distributors of the most common intestinal nematodosis (Vaz et al., 2017; El-Dakhly et al., 2019). The presence of nematodes in some organs (liver, trachea and lungs) of infected pigeons can have serious consequences for human health, especially when eating pigeons. It is also possible that domestic pigeons may serve as alternative hosts for some poultry helminths with which they interact and are closely related phylogenetically (Michel, 1974). Helminths that are localized in the intestines of birds significantly affect the functional activity of the immune system, cause immunodeficiency, reduce the natural reactivity of the infected organism (Biswal et al., 2016; Al Quraishy et al., 2020).

One of the most parasitic diseases for young pigeons is trichomonosis. Trichomonas gallinae is a virulent hepatotropic flagellate parasite of pigeons. Initially, the parasite infects the upper digestive tract, causing 
ulcers that allow it to enter the circulatory system. Then trichomonads enter the liver, where they cause the formation of caseous ulcers, which leads to serious losses and especially high mortality in young birds (Narcisi et al., 1991).

The causes of invasions are many, however, the most important factor is untimely diagnosis. The time spent on laboratory diagnosis of the disease and bringing the results of research to poultry owners often exceeds the time required for the development of the invasive process in poultry groups and does not ensure the timely implementation of the necessary measures. However, to date there are no data on the spread of endoparasitoses of domestic and wild pigeons in southern Ukraine. Therefore, a clinical examination, autopsy is a sufficient criterion for a preliminary diagnosis in order to take urgent measures to eliminate the disease and conduct health measures.

Given the urgency of this problem, we studied the spread of parasitic diseases (trichomonosis, cestodes, nematodes) and the species composition of pathogens in pigeons of different species in southern Ukraine.

\section{Materials and methods}

The research was conducted in the period from August to November 2018 and 2019 in the south of Ukraine (Odessa, Mykolaiv, Kherson regions). Animal experiments do not contradict the current legislation of Ukraine (Article 26 of the Law of Ukraine 5456-VI of 16.10.2012 "On protection of animals from cruel treatment") and "General ethical principles of animal experiments", adopted by the First National Congress on Bioethics (Kyiv, 2001) and international bioethical standards (materials of the IV European Convention for the Protection of Vertebrate Animals Used for Experimental and Other Purposes, Strasbourg, 1985) (Festing \& Wilkinson, 2007; Simmonds, 2017; Kabene \& Baadel, 2019). The research program was reviewed and approved by the Bioethics Commission of National Scientific Center "Institute of Experimental and Clinical Veterinary Medicine" in the current order. A total of 148 domestic and wild pigeons were studied. Domestic pigeons were studied in private collections, and wild pigeons were caught during sport hunting (Table 1).

To diagnose trichomonosis of pigeons, fresh wet smears were taken from the mucous membrane of the oral cavity and throat of birds, which were examined in the laboratory of epizootology and parasitology of the Odessa research station NSC "IECVM" by staining by the method of Romanovsky-Gimz using a light microscope with increasing $\times 400$ (Anderson et al., 2009). Trichomonas was identified by signs of mobility and the presence of flagella (Dovc et al., 2004).

To study intestinal parasites, a pathological examination was performed according to Fowler (1996), all helminths were collected in Petri dishes and counted under a dissecting microscope. The number of helminths obtained from one bird was determined and identified (Sepulveda \& Kinsella, 2013).

Postmortem dissection of poultry carcasses by Scriabin (1928) and collection of helminths was performed. The isolated nematodes were preserved in Barbagalo liquid, and cestodes - in 70\% ethyl alcohol. Determination of helminth species was carried out by morphology - nematodes after illumination in lactic acid with glycerol, and cestodes - after staining with lactic carmine. Differentiation of cestodes oncospheres (Raillietina, Davainea) was performed by staining eggs with diamond green at a dilution of 1:10000 and then the capsules were analyzed in Petri dishes. Oncospheres of Davainea proglottina were stained light green in 35 minutes, and oncospheres of Raillietina spp. during the time they were not painted (Ukrainian patent for utility model No. 78451).

\section{Results}

According to the results of studies of wet smears, it was found that all species of domestic and wild pigeons are carriers of Trichomonas gallinae. Out of 148 pigeons studied, 28 (18.9\%) individuals had pathogens of trichomonosis. The highest rate of infection was recorded in the wood pigeon Columba palambus 9 (32.1\%) and the domestic (feral) pigeon C. livia domestica $11(27.5 \%)$. Also infected were 5 (12.5\%) collared doves Streptopelia decaocto and 3 (7.5\%) turtle doves S. turtur (Table 2). The infestation rate of pigeons of different species with the causative agent of trichomonosis depends on sex. The total invasiveness of males was $21.1 \%$, while that of females was $16.7 \%$. Male C. palambus (38.5\%) and C. livia domestica $(30.0 \%)$ were the most infested, while females were infested at $26.7 \%$ and $25.0 \%$, respectively (Table 3 ).

Table 1

Information about the studied pigeons in the south of Ukraine

\begin{tabular}{llccr}
\hline Common name & \multicolumn{1}{c}{ Scientific name } & Males & Females & Total \\
\hline Domestic pigeon & Columba livia domestica (Gmelin, 1789) & 20 & 20 & 40 \\
Wood pigeon & Columba palambus (Linnaeus, 1758) & 13 & 15 & 28 \\
Common dove & Streptopelia turtur (Linnaeus, 1758) & 22 & 18 & 40 \\
Collared dove & Streptopelia decaocto (Frivaldszky, 1838) & 21 & 19 & 40 \\
& $\quad$ Total: & 76 & 72 & 148 \\
\hline
\end{tabular}

Table 2

Infection of domestic and wild pigeons with trichomonosis in the south of Ukraine

\begin{tabular}{lccc}
\hline \multicolumn{1}{c}{ Types of pigeons } & Number of examined & Number of infested & \% infested \\
\hline C. livia domestica & 40 & 11 & 27.5 \\
C. palambus & 28 & 9 & 32.1 \\
S. turtur & 40 & 3 & 7.5 \\
S. decaocto & 40 & 5 & 12.5 \\
$\quad$ Total: & 148 & 28 & 18.9 \\
\hline
\end{tabular}

Table 3

Distribution of trichomonosis in domestic and wild pigeons depending

\begin{tabular}{|c|c|c|c|c|c|c|}
\hline \multirow{3}{*}{$\begin{array}{c}\text { Types } \\
\text { of pigeons }\end{array}$} & \multicolumn{3}{|c|}{ males } & \multicolumn{3}{|c|}{ females } \\
\hline & \multirow{2}{*}{$\begin{array}{c}\text { researched, } \\
\text { heads }\end{array}$} & \multicolumn{2}{|c|}{ infested } & \multirow{2}{*}{$\begin{array}{l}\text { researched, } \\
\text { heads }\end{array}$} & \multicolumn{2}{|c|}{ infested } \\
\hline & & heads & $\%$ & & heads & $\%$ \\
\hline C. livia domestica & 20 & 6 & 30.0 & 20 & 5 & 25.0 \\
\hline C.palambus & 13 & 5 & 38.5 & 15 & 4 & 26.7 \\
\hline S. turtur & 22 & 2 & 9.1 & 18 & 1 & 5.6 \\
\hline S. decaocto & 21 & 3 & 14.3 & 19 & 2 & 10.5 \\
\hline Total: & 76 & 16 & 21.1 & 72 & 12 & 16.7 \\
\hline
\end{tabular}

According to the research results, the general level of infestation of pigeons with cestodes was $28.4 \%$. C. palambus 17 (60.7\%) and C. livia domestica $13(32.5 \%)$ were the most infested with cestodes. The infestation of $S$. turtur and $S$. decaocto was $12.5 \%$ and $17.5 \%$, respectively (Table 4).

\section{Table 4}

Infection of domestic and wild pigeons with cestodes in the south of Ukraine

\begin{tabular}{lccc}
\hline \multicolumn{1}{c}{ Types of pigeons } & $\begin{array}{c}\text { Number of ex- } \\
\text { amined }\end{array}$ & Number of infested & \% infested \\
\hline C. livia domestica & 40 & 13 & 32.5 \\
C. palambus & 28 & 17 & 60.7 \\
S. turtur & 40 & 5 & 12.5 \\
S. decaocto & 40 & 7 & 17.5 \\
\multicolumn{1}{c}{ Total: } & 148 & 42 & 28.4 \\
\hline
\end{tabular}

When determining the level of general infestation of pigeons with cestodes, no significant differences from sex were registered. Thus, the incidence of males was $30.3 \%$, and females $-26.4 \%$ (Table 5).

Table 5

Distribution of cestodes in domestic and wild pigeons depending on sex

\begin{tabular}{|c|c|c|c|c|c|c|}
\hline \multirow{3}{*}{ Types of pigeons } & \multicolumn{3}{|c|}{ males } & \multicolumn{3}{|c|}{ females } \\
\hline & \multirow{2}{*}{$\begin{array}{l}\text { researched, } \\
\text { heads }\end{array}$} & \multicolumn{2}{|c|}{ infested } & \multirow{2}{*}{$\begin{array}{l}\text { researched, } \\
\text { heads }\end{array}$} & \multicolumn{2}{|c|}{ infested } \\
\hline & & heads & $\%$ & & heads & $\%$ \\
\hline C. livia domestica & 20 & 6 & 30.0 & 20 & 7 & 35.0 \\
\hline C.palambus & 13 & 10 & 76.9 & 15 & 7 & 46.7 \\
\hline S. turtur & 22 & 3 & 13.6 & 18 & 2 & 11.1 \\
\hline S. decaocto & 21 & 4 & 19.1 & 19 & 3 & 15.8 \\
\hline Total: & 76 & 23 & 30.3 & 72 & 19 & 26.4 \\
\hline
\end{tabular}

In the studied 148 pigeons $34(22.9 \%)$ were affected by nematodes. C. livia domestica $21(52.5 \%)$ and S. decaocto $9(22.5 \%)$ were the most infected and only one S. turtur (2.5\%) was infected (Table 6).

In a study of the species composition of cestodes in pigeons, it was found that the most common species was Raillietina spp. The highest 
infestation was in C. palambus $-82.4 \%$ with an intensity of 2.6 specimens/bird, in C. livia domestica $-76.9 \%$ with a lesion intensity of 4.3 specimens/bird. Invasion of $S$. decaocto with Raillietina spp. was $71.4 \%$, and $S$. turtur $-60.0 \%$. The pathogen Davainea proglottina was registered only in two pigeons $C$. livia domestica $(15.4 \%)$ and $S$. decaocto (28.6\%). Three (17.6\%) C. palambus and one C. livia domestica (7.7\%) hosted the cestode Echinolepis carioca (Table 7).

\section{Table 6}

Infection of domestic and wild pigeons by nematodes in the south of Ukraine

\begin{tabular}{lccc}
\hline \multicolumn{1}{c}{ Types of pigeons } & Number of examined & Number of infested & \% infested \\
\hline C. livia domestica & 40 & 21 & 52.5 \\
C. palambus & 28 & 3 & 10.7 \\
S. turtur & 40 & 1 & 2.5 \\
S. decaocto & 40 & 9 & 22.5 \\
\multicolumn{1}{c}{ Total: } & 148 & 34 & 22.9 \\
\hline
\end{tabular}

Table 7

Species composition of cestodes

in domestic and wild pigeons in the south of Ukraine

\begin{tabular}{lccccc}
\hline \multirow{1}{*}{ Cestodes } & \multicolumn{3}{c}{$\begin{array}{c}\text { Number of infested pigeons / intensity } \\
\text { of invasion (specimens/bird) }\end{array}$} & $\begin{array}{c}\text { Total } \\
\text { infested }\end{array}$ \\
\cline { 2 - 5 } & $\begin{array}{c}\text { C. livia } \\
\text { domestica }\end{array}$ & C.palambus & S. turtur & S. decaocto & \\
\hline Raillietina spp. & $10(4.3)$ & $14(2.6)$ & $5(1.4)$ & $5(2.5)$ & 34 \\
Davainea proglottina & $2(6.2)$ & 0 & 0 & $2(3.0)$ & 4 \\
Echinolepis carioca & $1(2.0)$ & $3(1.6)$ & 0 & 0 & 4 \\
\hline
\end{tabular}

Three species of nematodes were identified in pigeons: Heterakis gallinarum, Ascaridia columbae and Capillaria spp. The nematodes H. gallinarum most heavily infested C. palambus $(66.7 \%)$ and $S$. decaocto $(33.3 \%)$. The helminth $A$. columbae was most recorded in C. livia domestica (57.1\%) and S. decaocto (44.4\%) with an intensity of 5.1 specimens/bird and 3.7 specimens/bird, respectively. In S. turtur, nematodes $H$. gallinarum and A. columbae were not registered. Helminths Capillaria spp. were identified in all species of pigeons (Table 8).

\section{Table 8}

Species composition of nematodes

in domestic and wild pigeons in the south of Ukraine

\begin{tabular}{lccccc}
\hline & \multicolumn{3}{c}{$\begin{array}{c}\text { Number of infested pigeons/intensity } \\
\text { of invasion (specimens/bird) }\end{array}$} & $\begin{array}{c}\text { Total } \\
\text { infested }\end{array}$ \\
\cline { 2 - 5 } & $\begin{array}{c}\text { C. livia } \\
\text { domestica }\end{array}$ & C.palambus & S. turtur & S. decaocto & \\
\hline H. gallinarum & $5(9.1)$ & $2(6.2)$ & 0 & $3(4.3)$ & 10 \\
A. columbae & $12(5.1)$ & 0 & 0 & $4(3.7)$ & 16 \\
Capillaria spp. & $4(8.5)$ & $1(4.0)$ & $1(3.0)$ & $2(3.4)$ & 8 \\
\hline
\end{tabular}

\section{Discussion}

Monitoring for diseases of any etiology, among which the main place in this research is occupied by parasitoses of pigeons is and remains an important stage of control in scientific and practical terms, both from an epizootic and ecological point of view. The study of the species composition of parasites and their infection of birds is of great interest not only to parasitologists, zoologists and ecologists, but also to veterinary specialists. This provides an opportunity to create a modern information base for indepth study of the helminthological situation in some parts of the country in order to develop concepts for controlling and managing the invasive process in groups of birds, ensuring parasitological safety of natural ecosystems and developing measures to combat parasitic diseases (Kumar et al., 2015; Maqbool et al., 2017).

Pigeon trichomonosis is a disease caused by flagellate protozoa (T. gallinae) commonly found in the upper digestive tract of pigeons and bird predators that feed on pigeons (Borji et al., 2011; Girard et al., 2014). Trichomonosis is a common disease worldwide. Researchers from Libya note that $55.0 \%$ of the studied pigeons are affected by T. gallinae (Alkharigy et al., 2018). According to the authors from the province of Babylon, Iraq, the highest level of Trichomonus gallinae infection was registered in wood pigeon $16(53.3 \%)$, followed by rock dove, domestic pigeon, collared dove and palm dove $12(40.0 \%), 9(30.0 \%), 4(13.3 \%)$ and 2 (11.1\%), respectively (Al-Rammahi et al., 2013). In the United Kingdom, trichomonosis was first detected in $86.0 \%$ of Streptopelia turtur, $86.0 \%$ of collared doves $S$. decaocto, $47.0 \%$ of wood pigeons $C$. palumbus and $40.0 \%$ of stock doves $C$. oenas (Lennon et al., 2013). Similar data on the prevalence of trichomonosis in wild pigeons were obtained by researchers in Western and Southern Europe (Marx et al., 2017). It is noted that in a small flock of $S$. decaocto and S. risoria numbering 200 head, mortality from trichomoniasis can reach $15-20 \%$. Ninety-four percent $(17 / 18)$ of affected birds had multiple lesions. Oral lesions spread by $33.0 \%(6 / 18)$ to the orbit of the eye and $11.0 \%(2 / 18)$ to the entire head area (Stimmelmayr et al., 2012). The prevalence of trichomonosis among common pigeons in Spain was found to be $34.2 \%$ (Villanua et al., 2006), in southern Khorasan in Iran - 57.8\% (Radfar et al., 2011), in Iraq $39.2 \%$ (Al-Barwari et al., 2012), in the province of Kvaliobia, Egypt 68.9\% (Abd El-Rahman et al., 2008), and in Colombia - 40.0\% (PérezGarcía et al., 2015). Adult birds can remain infected for a year or more and are a constant source of infection for their squabs (Jayentakumar Singh \& Mohilal, 2017).

Both domestic and wild pigeons feed mainly on grain, but consume beetles, snails, earthworms, and ants, which can be carriers of invasive stages of helminths (Bogach et al., 2020). The prevalence and level of infestation of birds varies depending on the type of parasite, the physiological condition of the individual, as well as the geographical location of the natural-climatic zone (Oniye et al., 2000). Endoparasites are represented by nematodes Ascaridia columbae (30.0\%), Dispharynx spiralis (10.0\%) and cestodes Raillietina spp. (80.0\%) found in clinically healthy pigeons (Mushi et al., 2000). Domestic pigeons in northwestern Nigeria are infected with intestinal parasites: cestodes - Raillietina tetragona 20 (13.8\%), R. echinobothrida 11 (7.6\%), Davainea proglottina 10 (6.9\%) and Amoebotaenia cuneata 5 (3.5\%), as well as nematodes Capillaria spp. 10 (6.9\%) (Mohammed et al., 2019). In the Zaria region of northern Nigeria, $116(48.3 \%)$ of the pigeons surveyed were infected with 9 species of helminths, including 6 species of cestodes and 3 species of nematodes. The species composition of cestodes is represented by Raillietina tetragona 65 (27.1\%), R. echinobothrida 26 (10.6\%), Hymenolepis cantaniana 4 (1.7\%), H. carioca 3 (1.3\%), R. cesticillus 1 (0.5\%) and Amoebotaenia cuneata $2(0.8 \%)$, and nematodes - Ascaridia columbae 27 (11.3\%), A. galli 8 (3.3\%) and Heterakis gallinarum 8 (3.3\%) (Adang et al., 2008). The most common helminths in S. decaocto from Florida were Ascaridia columbae (73.0\%), Fuhrmannetta crassula (28.6\%), Ornithostrongylus quadriradiatus (12.7\%) and Bruscapillaria obsignata (11.1\%) (Bean et al., 2005). In Bristol Zoo endoparasites in domestic and wild pigeons were represented by cestodes and nematodes (Carrera-Játiva et al., 2018). In Southern Texas 12 species of helminths were found in domestic and wild pigeons ( 9 nematodes and 3 cestodes). In general the distribution of helminths was similar regardless of pigeons' sex (Smith et al., 2012). Also, domestic pigeons in Turkey were observed to have no significant differences in the distribution of helminths depending on age and sex of the birds (Smith et al., 2012).

Cestodes parasitize in the small intestine (duodenum and ileum) - an area rich in half-digested food and which promotes the absorption of nutrients through the surface of the body. The presence of several cestodes in the intestine causes its obstruction, which leads to high levels of depletion, weight loss and even death of the bird (Radfar et al., 2012).

\section{Conclusion}

It has been proved that in the south of Ukraine endoparasitoses of domestic and wild pigeons is a fairly common invasive disease caused by Trichomonas gallinae, Raillietina spp., Davainea proglottina, Echinolepis carioca, H. gallinarum, A. columbae, Capillaria spp. Columba livia domestica pigeons are infected with trichomonosis and nematodes (A. COlumbae), C. palambus pigeons are diagnosed with trichomonosis and cestodes (Raillietina spp.). Streptopelia turtur pigeons are affected by cestodes (Raillietina spp.) and S. decaocto are infested with cestodes (Raillietina spp.) and nematodes (H. gallinarum, A. columbae). Monitoring of pigeon parasitosis should be continuous, as pigeons, in most cases, come 
into contact with other species of poultry and can be carriers of invasive pathogens.

\section{References}

Abd El-Rahman, M. A. M., Seddiek, S. A., \& Soliman, A. S. (2008). Some studies on trichomoniasis of pigeons at Qualiobia governorate. Egyptain Journal of Comparative Pathology and Clinical Pathology, 21(2), 123-141.

Adang, K. L., Onie, S. J., Ajanusi, O. D., Ezilor, A. Y., \& Abdu, P. A. (2008). Gastrointestinal helminths of domestic pigeons (Columba livia domestica Gmelin, 1789 Aves: Columbidae) in Zaria, Northern Nigeria. Science World Journal, 3(1), 33-37.

Al Quraishy, S., Abdel-Gaber, R., Dkhil, M. A., \& Alzuabi, K. (2020). Morphological and molecular characteristics of the gastro-intestinal nematode parasite $\mathrm{Asca}$ ridia columbae infecting the domestic pigeon Columba livia domestica in Saudi Arabia. Acta Parasitologica, 65(1), 208-224.

Al-Barwari, S., \& Saeed, I. (2012). The parasitic communities of the rock pigeon Columba livia from Iraq: Component and importance. Turkish Joumal of Parasitology, 36(4), 232-239.

Ali, M., Ibrahim, R., Alahmadi, S., \& Elshazly, H. (2020). Ectoparasites and intestinal helminths of pigeons in Medina, Saudi Arabia. The Journal of Parasitology, 106(6), 721-729.

Alkharigy, F. A., El Naas, A. S., \& El Maghrbi, A. A. (2018). Survey of parasites in domestic pigeons (Columba livia) in Tripoli, Libya. Open Veterinary Joumal, 8(4), 360-366.

Al-Rammahi, H. M., Al-Hasnawy, M. H., \& Abbas, A. K. (2013). Concurrent infection of cestodes with trichomoniasis in domestic and wild Columbides birds in Babylon province. The Iraqi Journal of Veterinary Medicine, 37(2), 192-198.

Anderson, N. L., Grahn, R. A., Van-Hoosear, K., \& Bondurant, R. H. (2009). Studies of trichomonal protozoa in free ranging songbirds: Prevalence of Trichomonas gallinae in house finches (Carpodacus mexicanus) and corvids and a novel trichomonad in mockingbirds (Mimus polyglottos). Veterinary Parasitology, 161, 178-186.

Bean, D. L., Rojas-Flores, E., Foster, G. W., Kinsella, J. M., \& Forrester, D. J. (2005) Parasitic helminths of Eurasian collared-doves (Streptopelia decaocto) from Florida. The Joumal of Parasitology, 91(1), 184-187.

Biswal, D., Nandi, A. P., \& Chatterjee, S. (2016). Helminth-bacteria interaction in the gut of domestic pigeon Columba livia domestica. Journal of Parasitic Diseases, 40(1), 116-123.

Bogach, M. V., Paliy, A. P., Perots'ka, L. V., Pyvovarova, I. V., Stoyanova, V. Y., \& Palii, A. P. (2020). The influence of hydro-meteorological conditions on the spread of chicken cestodiasis. Regulatory Mechanisms in Biosystems, 11(3), 414418.

Borji, H., Razmi, G. H., Movassaghi, A. H., Moghaddas, E., \& Azad, M. (2011) Prevalence and pathological lesion of Trichomonas gallinae in pigeons of Iran. Journal of Parasitic Diseases, 35(2), 186-189.

Boyko, A. A., \& Brygadyrenko, V. V. (2017). Changes in the viability of Strongyloides ransomi larvae (Nematoda, Rhabditida) under the influence of synthetic flavourings. Regulatory Mechanisms in Biosystems, 8(1), 36-40.

Boyko, O. O., \& Brygadyrenko, V. V. (2018). The impact of certain flavourings and preservatives on the survivability of larvae of nematodes of Ruminantia. Regulatory Mechanisms in Biosystems, 9(1), 118-123.

Boyko, O. O., \& Brygadyrenko, V. V. (2019). The impact of acids approved for use in foods on the vitality of Haemonchus contortus and Strongyloides papillosus (Nematoda) larvae. Helminthologia, 56(3), 202-210.

Carrera-Játiva, P. D., Morgan, E. R., Barrows, M., \& Wronski, T. (2018). Gastrointestinal parasites in captive and free-ranging birds and potential cross-transmission in a zoo environment. Journal of Zoo and Wildlife Medicine, 49(1), 116-128.

Dovc, A., Zorman-Rojs, O., Vergles-Rataj, A., Bole-Hribovsek, V., Krapez, U., \& Dobeic, M. (2004). Health status of free-living pigeons (Columba livia domesti$c a$ ) in the city of Ljubljana. Acta Veterinaria Hungarica, 52(2), 219-226.

El-Dakhly, K. M., El-Seify, M. A., Mohammed, E. S., Elshahawy, I. S., Fawy, S. A., \& Omar, M. A. (2019). Prevalence and distribution pattern of intestinal helminths in chicken and pigeons in Aswan, Upper Egypt. Tropical Animal Health and Production, 51(3), 713-718

Festing, S., \& Wilkinson, R. (2007). The ethics of animal research. Talking Point on the use of animals in scientific research. EMBO Reports, 8(6), 526-530.

Girard, Y. A., Rogers, K. H., Woods, L. W., Chouicha, N., Miller, W. A., \& Johnson, C. K. (2014). Dual-pathogen etiology of avian trichomonosis in a declining band-tailed pigeon population. Infection, Genetics and Evolution: Joumal of Molecular Epidemiology and Evolutionary Genetics in Infectious Diseases, 24 146-156.

Hembram, A., Panda, M. R., Mohanty, B. N., Pradhan, C. R., Dehuri, M., Sahu, A., \& Behera, M. (2015). Prevalence of gastrointestinal helminths in Banaraja fowls reared in semi-intensive system of management in Mayurbhanj district of Odisha. Veterinary World, 8(6), 723-726.
Jayentakumar Singh, L., \& Mohilal, N. (2017). Gastrointestinal parasitic infection in diverse species of domestic birds of Manipur, India. Joumal of Parasitic Diseases, 41(1), 142-146.

Kabene, S., \& Baadel, S. (2019). Bioethics: A look at animal testing in medicine and cosmetics in the UK. Journal of Medical Ethics and History of Medicine, 12, 15.

Kumar, S., Garg, R., Ram, H., Maurya, P. S., \& Banerjee, P. S. (2015). Gastrointestinal parasitic infections in chickens of upper gangetic plains of India with special reference to poultry coccidiosis. Journal of Parasitic Diseases, 39(1), 22-26.

Lennon, R. J., Dunn, J. C., Stockdale, J. E., Goodman, S. J., Morris, A. J., \& Hamer, K. C. (2013). Trichomonad parasite infection in four species of Columbidae in the UK. Parasitology, 140(11), 1368-1376.

Leung, T. L., \& Koprivnikar, J. (2016). Nematode parasite diversity in birds: The role of host ecology, life history and migration. The Joumal of Animal Ecology, 85(6), 1471-1480.

Maqbool, I., Wani, Z. A., Shahardar, R. A., Allaie, I. M., \& Shah, M. M. (2017). Integrated parasite management with special reference to gastro-intestinal nematodes. Joumal of Parasitic Diseases, 41(1), 1-8.

Marx, M., Reiner, G., Willems, H., Rocha, G., Hillerich, K., \& Masello, J. F. (2017). High prevalence of Trichomonas gallinae in wild columbids across Western and Southern Europe. Parasites and Vectors, 10(1), 242.

Michel, J. F. (1974). Arrested development of nematodes and some related phenomena. Advances in Parasitology, 12, 279-366.

Mohammed, B. R., Simon, M. K., Agbede, R. I. S., \& Arzai, A. H. (2019). Prevalence of intestinal helminth parasites of pigeons (Columba livia domestica Gmelin 1789) in Kano State, North-Western Nigeria. Veterinary Parasitology: Regional Studies and Reports, 16, 100289.

Moravec, F., \& Scholz, T. (2016). Helminth parasites of the lesser great cormorant Phalacrocorax carbo sinensis from two nesting regions in the Czech Republic. Folia Parasitologica, 63, 22

Mushi, E. Z., Binta, M. G., Chabo, R. G., Ndebele, R., \& Panzirah, R. (2000). Parasites of domestic pigeons (Columba livia domestica) in Sebele, Gaborone, Botswana. Joumal of the South African Veterinary Association, 71(4), 249-250.

Nakao, M., Sasaki, M., Waki, T., Iwaki, T., Morii, Y., Yanagida, K., Watanabe, M., Tsuchitani, Y., Saito, T., \& Asakawa, M. (2019). Distribution records of three species of Leucochloridium (Trematoda: Leucochloridiidae) in Japan, with comments on their microtaxonomy and ecology. Parasitology International, 72, 101936.

Narcisi, E. M., Sevoian, M., \& Honigberg, B. M. (1991). Pathologic changes in pigeons infected with a virulent Trichomonas gallinae strain (Eiberg). Avian Diseases, 35(1), 55-61.

Oniye, S. J., Audu, P. A., Adebote, D. A., Kwaghe, B. B., Ajanusi, O. J., \& Nfor, M. B. (2000). Survey of helminth parasites of laughing dove (Streptopelia segalensis) in Zaria, Nigeria. African Journal of Natural Sciences, 4, 65-66.

Paliy, A. P., Sumakova, N. V., Petrov, R. V., Berezovskiy, A. V., Risovaniy, V. I., Zon, G. A., Ivanovskaya, L. B., Fotin, A. I., Dolbanosova, R. V., Livoshchenko, L. P., Livoshchenko, Y. M., \& Palii, A. P. (2020). Endoparasic diseases of ostriches in eastern Ukraine. Ukrainian Journal of Ecology, 10(4), 235-241.

Pérez-García, J., Monsalve-Arcila, D., \& Márquez-Villegas, C. (2015). Presencia de parásitos y enterobacterias en palomas ferales (Columba livia) en áreas urbanas en Envigado, Colombia. Revista Facultad Nacional de Salud Pública, 33(3), $370-376$.

Piasecki, T. (2006). Evaluation of urban pigeon (Columbia livia f. urbana) health status in relation to their threat to human's health. Medycyna Weterynaryjna, 62, 531-535.

Radfar, M. H., Fathi, S., Asl, E. N., Dehaghi, M. M., \& Seghinsara, H. R. (2011). A survey of parasites of domestic pigeons (Columba livia domestica) in South Khorasan, Iran. Veterinary Research, 4(1), 18-23.

Radfar, M. H., Khedri, J., Adinehbeigi, K., Nabavi, R., \& Rahmani, K. (2012). Prevalence of parasites and associated risk factors in domestic pigeons (Columba livia domestica) and free-range backyard chickens of Sistan region, east of Iran. Journal of Parasitic Diseases, 36(2), 220-225.

Rohde, K. (1994). Niche restriction in parasites: Proximate and ultimate causes. Parasitology, 109, 69-84

Senlik, B., Gulegen, E., \& Akyol, V. (2005). Effect of age, sex and season on the prevalence and intensity of helminth infections in domestic pigeons (Columba livia) from Bursa Province, Turkey. Acta Veterinaria Hungarica, 53(4), 449- 456.

Sepulveda, M. S., \& Kinsella, J. M. (2013). Helminth collection and identification from wildlife. Joumal of Visualized Experiments, 82, e51000.

Simmonds, R. C. (2017). Chapter 4. Bioethics and animal use in programs of research, teaching, and testing. In: Weichbrod, R. H., Thompson, G. A. H., Norton, J. N. (Eds.). Management of animal care and use programs in research, education, and testing. 2nd edition. CRC Press, Taylor \& Francis, Boca Raton Pp. 1-28.

Smith, A. J., \& Fedynich, A. M. (2012). Helminth community composition, structure, and pattern in six dove species (Columbiformes: Columbidae) of South Texas. The Journal of Parasitology, 98(1), 11-21.

Stimmelmayr, R., Stefani, L. M., Thrall, M. A., Landers, K., Revan, F., Miller, A Beckstead, R., \& Gerhold, R. (2012). Trichomonosis in free-ranging Eurasian 
collared doves (Streptopelia decaocto) and African collared dove hybrids (Streptopelia risoria) in the Caribbean and description of ITS-1 region genotypes. Avian Diseases, 56(2), 441-445.

Vaz, F. F., Silva, L. A. F. D., Ferreira, V. L., Silva, R. J. D., \& Raso, T. F. (2017) Gastrointestinal helminths of two populations of wild pigeons (Columba livia) in Brazil. Brazilian Journal of Veterinary Parasitology, 26(4), 446-450.
Villanua, D., Hofle, U., Perez-Rodriguez, L., \& Gortazar, C. (2006). Trichomonas gallinae in wintering common wood pigeons Columba palumbus in Spain. International Joumal of Avian Science, 148(4), 641-648. 